\title{
Kadar Kolesterol Plasma Tikus Wistar pada Pemberiak Ekstrak Etanol dan Helssana dari Daun Gedi Merah (Abelmoschus manihot L.)
}

\author{
Tanza A. Tubagusa*, Lidya I. Momuata, Julius S. Pontoha \\ aJurusan Kimia, FMIPA, Unsrat, Manado
}

K A T A K U C I

Abelmoschus manihot L., Kolesterol

Metode biosensor

amperometrik

K E YW O R S

Abelmoschus manihot L.

Cholesterol

Amperometric biosensor

method

$\overline{\overline{\text { AVAILABLE ONLINE }}}$

\begin{abstract}
A B S T R A K
Telah dilakukan penelitian untuk mempelajari pengaruh pemberian ekstrak etanol dan heksana dari daun gedi merah terhadap kadar kolesterol plasma tikus wistar yang diberi pakan aterogenik. Penelitian ini menggunakan 20 ekor tikus jantan, berumur 2-3 bulan dengan berat 130200 g, yang dibagi dalam 4 kelompok perlakuan secara acak, yaitu kelompok $\mathrm{K}$ diberi pakan beras jagung, kelompok $\mathrm{K}$ - diberi pakan aterogenik, sedangkan kelompok P1 dan P2 diberi ekstrak etanol dan heksana dengan dosis $20 \mathrm{mg} / \mathrm{KgBB}$. Setiap perlakuan terdiri dari 5 ekor tikus yang dilakukan 5 kali pemeriksaan kadar kolesterol dengan metode biosensor amperometrik dengan menggunakan alat ukur NESCO GCU. Data yang diperoleh dari pemeriksaan dianalisis menggunakan ANOVA satu arah <(0,005). Hasil penelitian menunjukkan bahwa ekstrak heksana dan ekstrak etanol daun gedi merah dengan dosis $20 \mathrm{mg} / \mathrm{kgBB}$ dapat menurunkan kadar kolesterol sebesar $72 \%$ atau sekitar $12,8 \mathrm{mg} / \mathrm{dL}$ dan $14 \%$ atau sekitar $2,4 \mathrm{mg} / \mathrm{dL}$, dibandingkan dengan dengan kelompok K-.

A B S T R A C T

The research had been done with the purpose were to study the influence of granting the ethanol and hexane extract of red gedi leaves on Wistar rats plasma cholesterol levels which were fed by atherogenics. This study used about 20 male rats, Wistar rats aged 2-3 months with a weight 130-200 g were divided into 4 groups randomly, for the grop of $\mathrm{K}$ were fed corn rice, group of $\mathrm{K}$ - were fed atherogenics, while the P1 and P2 were given ethanol and hexane extract with a dose of $20 \mathrm{mg} / \mathrm{KgBW}$. Each treatment consisted of 5 rats were performed 5 times cholesterol checks with amperometric biosensor method using a measuring instrument NESCO GCU. Data obtained from the examination were analyzed using one-way ANOVA < $(0.005)$. The results showed that the hexane extract and red gedi leaf ethanol extract at a dose of $20 \mathrm{mg} / \mathrm{kg}$ body weight can low down the cholesterol levels by $72 \%$ or approximately $12.8 \mathrm{mg} / \mathrm{dL}$ and $14 \%$, or about $2.4 \mathrm{mg} / \mathrm{dL}$, compared with the group $\mathrm{K}$-.
\end{abstract}

\section{Pendahuluan}

Di Indonesia, angka penderita penyakit kardiovaskuler meningkat dari tahun ke tahun. Gaya hidup dan pola makan masyarakat modern yang cenderung mengkonsumsi makanan berlemak dan makanan cepat saji dalam jumlah banyak, serta kurangnya berolahraga merupakan kebiasaan buruk masyarakat yang dapat menimbulkan penyakit kardiovaskuler, seperti penyakit jantung koroner. Terjadinya penyakit jantung koroner berkorelasi positif dengan kadar kolesterol dalam darah.

Kolesterol merupakan senyawa steroid utama pada jaringan hewan. Kolesterol berperan penting dalam membran sel dan lipoprotein plasma, serta sebagai perkursor bagi hormon-hormon kelamin,

*Corresponding author: Jurusan Kimia FMIPA UNSRAT, Jl. Kampus Unsrat, Manado, Indonesia 95115; Email address: reysa.tubagus@yahoo.co.id Published by FMIPA UNSRAT (2015) 
vitamin D dan asam empedu (Murray et al., 2003). Kadar kolesterol yang tinggi dalam makanan yang dikonsumsi dapat meningkatkan kadar kolesterol dalam darah manusia dan beberapa hewan percobaan. Upaya untuk menurunkan kadar kolesterol yang tinggi dalam darah dengan menggunakan tumbuhan obat telah banyak dilakukan. Tanaman gedi (Abelmoschus manihot L. Medik) merupakan tumbuhan tropis yang secara tradisional telah lama dikenal di Sulawesi Utara sebagai tanaman sayuran. Masyarakat memanfaatkan daun gedi yang direbus tanpa garam sebagai obat tradisional, antara lain untuk sakit ginjal, maag, dan menurunkan kadar kolesterol yang tinggi dalam darah (Mamahit dan Soekamto, 2010).

Penelitian tentang tanaman gedi sehubungan dengan penurunan kadar kolesterol dalam darah telah dilaporkan oleh beberapa peneliti. Gani et al. (2013) melaporkan bahwa pemberian daun gedi merah dapat menurunkan kadar kolesterol total plasma (total plasma cholesterol, TPC) dari tikus wistar yang hiperkolesterolemia. Assagaf et al. (2013) mengemukakan bahwa ekstrak etanol daun gedi merah dapat menurunkan kadar kolesterol darah plasma tikus wistar sebesar 86,45\%. Kemampuan gedi merah dalam menurunkan kadar kolesterol darah dapat disebabkan oleh kandungan fitokimia yang ada dalam tanaman tersebut, seperti tanin, fenolik dan flavonoid (Novriani, 2009).

Sampai saat ini, belum diperoleh informasi tentang perbandingan pengaruh ekstrak etanol dan heksana dari daun gedi merah terhadap kadar kolesterol plasma. Untuk itulah penelitian ini dilakukan guna menguji kemapuan ekstrak etanol dan heksana daun gedi merah dalam menurunkan kadar kolesterol plasma.

\section{Metode}

\subsection{Bahan dan Alat}

Bahan-bahan yang digunakan dalam penelitian ini adalah daun gedi merah. Bahan kimia yang digunakan adalah etanol 96\% dan n-heksana (Merck) serta CMC 0,5\%. Hewan uji yang digunakan adalah tikus galur wistar jantan sebanyak 20 ekor, beras jagung, lemak kambing, kuning telur ayam. Alat yang digunakan dalam penelitian ini adalah alat-alat gelas, ayakan 60 mesh, penggiling, neraca analitik, kertas saring, gunting bedah, disposable syringe $3 \mathrm{~mL}$ Terumo, nasogatric tube (NGT) $35 \mathrm{~cm}$, rotary vacum evaporator Eyela N-100, oven Mammert, hot plate, kit dan strip kolesterol Nesco Glucose Choletsterol Uric acid (GCU) dan kandang tikus beserta kelengkapannya.

\subsection{Preparasi dan Ekstraksi Sampel}

Sampel daun gedi merah dibersihkan dengan air mengalir, ditiriskan, dikeringanginkan selama 5 hari, lalu dipotong-potong, kemudian digiling dan diayak menggunakan ayakan 60 mesh sehingga diperoleh serbuk sampel. Serbuk sampel 200 g masing-masing diekstraksi dengan menggunakan heksana $500 \mathrm{~mL}$ dan etanol $80 \%$ sebanyak $500 \mathrm{~mL}$ dengan metode maserasi selama 48 jam pada suhu $4{ }^{\circ} \mathrm{C}$, lalu disaring, kemudian filtrat dievaporasi untuk memisahkan ekstrak dengan pelarut, setelah itu ekstrak dikeringkan dalam oven.

\subsection{Pembuatan Pakan Aterogenik}

Pakan aterogenik dibuat dengan mencampurkan $100 \mathrm{~g}$ lemak kambing dan $50 \mathrm{~g}$ kuning telur dalam 1000 g pakan tikus berupa beras jagung. Lemak kambing dipanaskan terlebih dahulu hingga mencair dan kuning telur diperoleh dari telur yang telah direbus. Lemak kambing dan kuning telur kemudian dicampurkan ke dalam 1000 g beras jagung (Gani et al., 2013).

\subsection{Penyiapan dan Perlakuan Hewan Uji}

Tikus putih jantan yang digunakan ada 20 ekor dengan usia 2-3 bulan dan diadaptasikan terlebih dahulu selama 8 hari dengan diberikan pakan standar yaitu, beras jagung dan air yang diberi secara ad libitum. Setalah masa adaptasi, semua tikus diambil sampel darahnya melalui vena ekor untuk pengujian total plasma kolesterol awal tikus. Tikus kemudian dibagi menjadi 4 kelompok perlakuan secara acak, yaitu kelompok pakan standar (K), kelompok aterogenik (K-), kelompok aterogenik + ekstrak etanol daun gedi merah (P1) dan kelompok aterogenik + ekstrak heksana daun gedi merah (P2) dengan masing-masing konsentrasi ekstrak $2 \mathrm{mg} / \mathrm{mL}$, masing-masing kelompok perlakuan terdiri dari 5 ekor tikus.

Pemberian ekstrak etanol dan heksana untuk setiap tikus diberi dosis $20 \mathrm{mg} / \mathrm{kgBB}$ selama 28 hari yang dilakukan secara bersamaan. Pada setiap minggunya dilakukan pengambilan sampel darah melalui vena ekor untuk pengujian total plasma kolesterol yang menggunakan alat kolesterol.

\subsection{Proses Penginduksian Ekstrak pada Tikus Wistar}

Ekstrak kering daun gedi merah ditimbang sesuai dengan perhitungan dosis pada masing-masing tikus wistar. Ekstrak yang telah ditimbang, disuspensikan dengan CMC 0,5\% (m/v). Ekstrak yang telah disuspensikan kemudian diinduksi ke dalam tubuh tikus wistar menggunakan NGT atau sonde lambung. Pemberian ekstrak dilakukan per oral, yaitu dengan memasukkan selang NGT ke dalam saluran pencernaan tikus. Panjang selang NGT yang dimasukkanke dalam tubuh tikus bersisar $10-14 \mathrm{~cm}$. Proses induksi ini dilakukan setiap hari, selama masa perlakuan.

\subsection{Pengambilan Sampel Darah Tikus Wistar}

Pengambilan sampel darah tikus wistar dilakukan dalam dua tahap yaitu, setelah masa adaptasi selama 8 hari untuk mengetahui kadar total plasma kolesterol awal, setelah pemberian pakan standar dan pakan aterogenik dengan ekstak etanol dan $\mathrm{n}$-heksana daun gedi merah yang dilakukan pengambilan setiap minggunya. Tikus yang akan diambil sampel darahnya dipuasakan terlebih dahulu selama 12-18 jam. Ekor tikus dibersihkan dengan kapas yang telah diberi alkohol $70 \%$ agar kotoran 
yang terdapat pada ekor bisa terangkat. Selanjutnya darah diambil beberapa tetes pada bagian ekor yang telah dipotong, kemudian darah diteteskan pada strip kolesterol.

\subsection{Pemeriksaan Total Plasma Kolesterol}

Kadar total plasma kolesterol dilakukan dengan menggunakan alat ukur Nesco Glucose Choletsterol Uric acid (GCU) dengan detection limit 100-400 $\mathrm{mg} / \mathrm{dL}$, dengan bantuan strip pengujian kolesterol yang telah ditetesi darah tikus wistar.

\subsection{Analisa Data}

Analisa data penelitian dilakukan dengan membandingkan data antara kelompok perlakuan dengan uji ANOVA satu arah dan jika diperoleh hasil yang berbeda nyata, akan dilanjutkan dengan Duncan menggunakan program SPSS 17,0. ANOVA satu arah dan Duncan dianggap berbeda nyata secara statistika jika didapatkan harga $\mathrm{p}<0,05$ dengan tingkat kepercayaan $95 \%(\alpha=0,05)$.

\section{Hasil dan Pembahasan}

\subsection{Ektraksi Sampel}

Daun gedi merah diekstraksi menggunakan cara dingin yaitu metode maserasi pada suhu $4{ }^{\circ} \mathrm{C}$. Cara ini dipilih untuk meminimalisasi kerusakan senyawa kimia. Pelarut yang digunakan dalam penelitian ini adalah etanol dan heksana. Etanol digunakan untuk mengekstrak senyawa yang besifat relatif lebih polar, sedangkan heksana untuk mengekstrak senyawa yang relatif lebih non-polar. Konsentrasi etanol yang digunakan sebesar $80 \%$, karena adanya penambahan air dapat meningkatkan polaritas dari etanol. Peningkatan polaritas tersebut mengakibatkan pembesaran partikel tanaman dan meningkatkan difusi zat yang akan diekstraksi ke luar sel melalui pori-pori dinding sel (Tiwari et al., 2011). Ekstraksi yang dilakukan menggunakan pelarut n-heksana dimaksudkan untuk memisahkan senyawa-senyawa non-polar yang terdapat dalam daun gedi merah. Pelarut $n$-heksana termasuk pelarut non-polar, sehingga dapat melarutkan senyawa-senyawa nonpolar yang terdapat di dalamnya.

Rendemen yang dihasilkan pada proses ektraksi pelarut etanol dan heksana adalah 5,26\% dan 1,03\%. Rendemen ekstrak etanol lebih besar daripada ektrak heksana, yang berarti bahwa lebih banyak senyawa polar yang terekstrak dari daun gedi merah dibandingkan senyawa non-polar.

\subsection{Pengaruh Pemberian Pakan Aterogenik terhadap Berat Badan pada Tikus}

Pemberian pakan hiperkolesterolemia yang mengandung 5\% kuning telur dan 10\% lemak kambing meningkatkan kadar kolesterol dan berat badan tikus pada penelitian ini. Kuning telur dan lemak kambing merupakan sumber kolesterol hewan dan lemak yang dapat meningkatkan kadar kolesterol total dan trigliserida dalam darah (Murray et al., 2003). Meningkatnya kadar kolesterol setelah diberi pakan hiperkolesterolemia selama dua minggu dikarenakan tingginya kadar kolesterol dan asam lemak jenuh dalam pakan hiperkolesterolemia. Setiap asupan lemak jenuh 1\% dari total energi sehari diprediksi dapat meningkatkan $2,7 \mathrm{mg} / \mathrm{dL}$ kadar plasma kolesterol (Murray et al., 2003). Kuning telur merupakan komponen lemak tertinggi, yang terdiri atas $65,50 \%$ trigliserida, 5,20\% kolesterol dan $28,30 \%$ fosfolipid, atau mengandung kolesterol sekitar 270 mg/butir telur (Sirait,1986).

\section{Tabel 1 - Berat pakan yang dikonsumsi}

\begin{tabular}{|l|l|}
\hline Kelompok Perlakuan & Berat Pakan yang dikonsumsi \\
\hline$K$ & $10,46 \pm 0,99^{\mathrm{bd}}$ \\
\hline $\mathrm{K}-$ & $15,86 \pm 5,40^{\mathrm{a}}$ \\
\hline $\mathrm{P}_{1}$ & $19,82 \pm 4,02^{\mathrm{a}}$ \\
\hline $\mathrm{P}_{2}$ & $17,56 \pm 2,25^{\mathrm{a}}$ \\
\hline
\end{tabular}

Tabel 2 - Hasil pengukuran berat badan pada tikus selama perlakuan

\begin{tabular}{|c|c|c|c|c|c|c|c|}
\hline \multirow{2}{*}{$\begin{array}{l}\text { Kelompok } \\
\text { Perlakuan }\end{array}$} & \multicolumn{5}{|c|}{ Bobot Badan Tikus (g) Minggu Ke- } & \multirow{2}{*}{$\begin{array}{c}\text { Rata-rata Bobot } \\
\text { Badan Tikus (g) } \pm \\
\text { SD }\end{array}$} & \multirow{2}{*}{$\begin{array}{c}\text { Rata-rata } \\
\text { Kenaikan Bobot } \\
\text { Badan Tikus (g) }\end{array}$} \\
\hline & 0 & 1 & 2 & 4 & 6 & & \\
\hline K & 155,0 & 162,3 & 170,2 & 178,3 & 186,1 & $170,4 \pm 12,37$ & 7,8 \\
\hline K- & 132,0 & 143,4 & 150,4 & 163,2 & 165,4 & $150,9 \pm 13,92$ & 8,4 \\
\hline$P_{1}$ & 146,7 & 158,2 & 169,4 & 192,2 & 197,5 & $172,8 \pm 21,75$ & 13,1 \\
\hline $\mathrm{P}_{2}$ & 132,2 & 150,7 & 159,5 & 180,5 & 184,3 & $161,5 \pm 21,56$ & 12,7 \\
\hline
\end{tabular}

Dalam Tabel 1 dan 2, perlakuan hiperkolesterolemia dengan pemberian pakan aterogenik memperlihatkan adanya pertambahan berat badan yang signifikan pada semua kelompok tikus yang diujicobakan. Terlihat bahwa dengan pemberian pakan aterogenik sebanyak $30 \mathrm{~g} /$ hari 
cenderung meningkatkan berat badan. Hasil yang tercantum menunjukkan kenaikan berat badan pada keempat kelompok perlakuan, dimana kenaikan berat badan paling tinggi terdapat pada kelompok perlakuan P1 yang diberi perlakuan hiperkolesterolemia yang dibarengi dengan ekstrak daun gedi merah, dengan kenaikan berat badan sebesar 13,1 g dengan berat pakan yang dikonsumsi 19,82 g dibandingkan dengan kelompok perlakuan kontrol (K) yang hanya diberi pakan beras jagung berat badannya sebesar 7,8 g dengan berat pakan yang dikonsumsi 10,46 g. Pada Tabel 5, kelompok kontrol negtaif (K-) rata-rata berat badan 150,9 g lebih rendah dari rata-rata berat badan kelompok perlakuan yang lain. Lebih rendahnya kenaikan berat badan tikus pada kelompok tersebut terjadi karena beberapa hal, yaitu aktivitas dan nafsu makan pada hewan uji serta adanya serat dalam bahan baku pakan yang digunakan. Menurut Budiyono dan Chandra (2013), penurunan berat badan oleh serat dilakukan dengan cara meningkatkan asam lemak bebas serta kolesterol dalam bentuk asam empedu ketika dalam saluran pencernaan, kemudian melalui feses. Serat juga difermentasikan oleh mikroflora di dalam usus sehingga menghasilkan asam asetat, propionat dan butirat yang dapat mengambat kolesterol.

Namun, kenaikan berat badan ini juga dapat disebabkan karena asupan lemak dan gizi yang lainnya yang ada pada pakan aterogenik. Pakan aterogenik dan berat badan pada tikus ini berkolesrasi sangat penting, karena pada kelompok perlakuan yang diberikan pakan tinggi kolesterol menambah nafsu makan tikus karena pakan aterogenik yang dicampurkan dengan kuning telur, lemak kambing dan beras jagung memiliki bau yang khas sehingga memperlihatkan adanya pertambahan berat badan yang signifikan setiap minggunya dibandingkan dengan kelompok perlakuan yang hanya diberikan beras jagung.

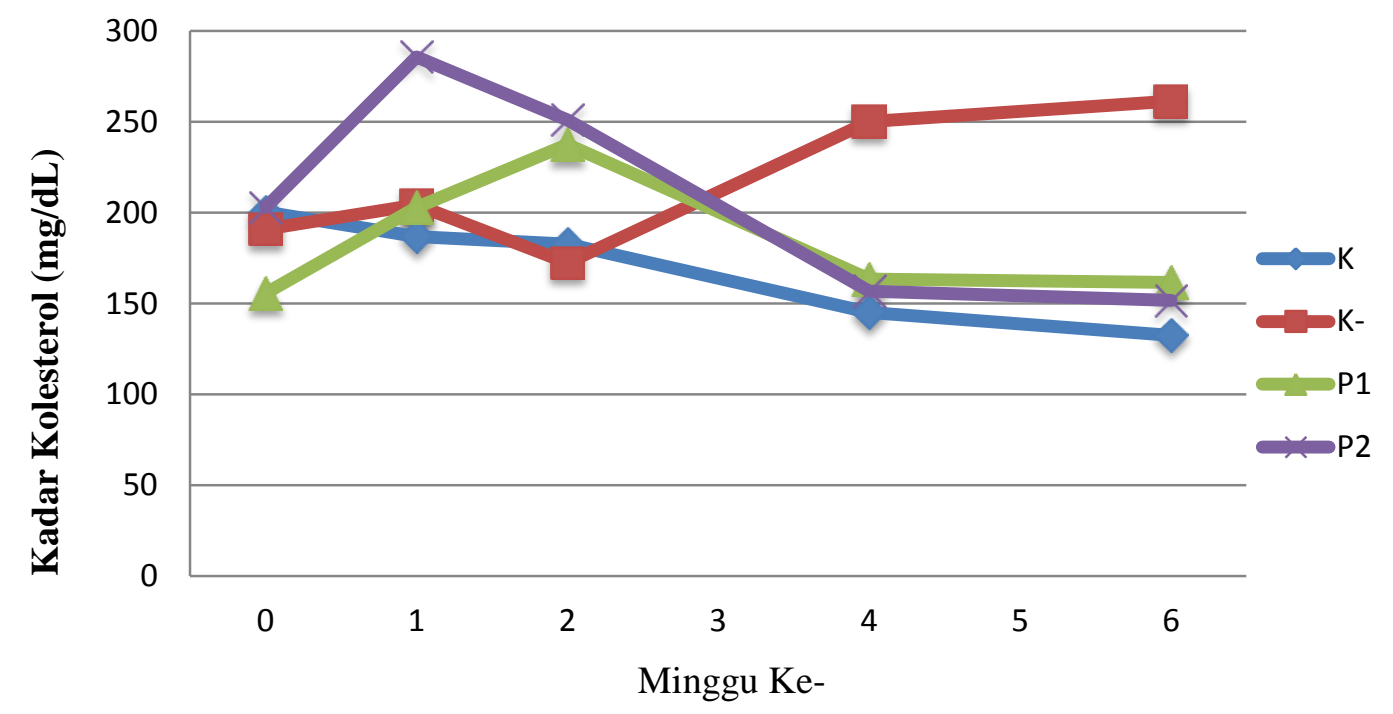

Gambar 1 - Grafik hasil peningkatan Total Plasma Cholesterol (TPC) pada tikus (Ket: K: Kelompok Perlakuan Kontrol diberi beras jagung, K(-): Kelompok Perlakuan Kontrol Negatif diberi Pakan Aterogenik, $\mathrm{P}_{1:}$ Kelompok Perlakuan Pakan Aterogenik + Ekstrak Etanol Daun Gedi Merah 20 mg/kgBB, P2: Kelompok Perlakuan Pakan Aterogenik + Ekstrak Heksana Daun Gedi Merah 20 mg/kgBB)

\subsection{Pengujian Efek Ekstrak Daun Gedi Merah terhadap Kadar Total Plasma Cholesterol (TPC)}

Kenaikan kolesterol atau keadaan hiperkolesterolemia yang terjadi pada tikus dengan pemberian pakan tinggi lemak sebanyak $30 \mathrm{~g} / \mathrm{hari}$ selama 6 minggu dapat dilihat pada Gambar 1.

Rata-rata kadar kolesterol total darah pada tikus hasil perlakuan hiperkolesterolemia menunjukkan bahwa pada kelompok perlakuan K-, P1 dan P2 berbeda dengan kelompok perlakuan $\mathrm{K}$ yang tidak dikenakan perlakuan apa pun. Hal ini dikarenakan pakan yang diberikan pada kelompok perlakuan $\mathrm{K}$ hanya berupa beras jagung, tanpa dimodifikasi dengan lemak. Peningkatan kadar kolesterol setelah pemberian pakan tinggi lemak ini menunjukkan bahwa konsumsi tinggi lemak merupakan salah satu faktor penyebabnya adalah hiperkolesterolemia.

Menurut Masrufi (2009), kadar kolesterol dalam darah selalu berubah-ubah di setiap waktu, meskipun perubahan ini tidak seberapa bedanya. Banyak faktor yang memengaruhinya terutama faktor genetik, umur, dan lingkungan. Selain itu, stres juga dapat memicu meningkatnya kolesterol. Perubahan pola makan juga berperan dalam perubahan kadar kolesterol dalam darah.

Berdasarkan Gambar 7, kenaikan kolesterol yang paling tinggi ditunjukkan pada kelompok perlakuan K$(215,73 \mathrm{mg} / \mathrm{dL}), \mathrm{P} 1(184,17 \mathrm{mg} / \mathrm{dL})$ dan P2 (209,56 $\mathrm{mg} / \mathrm{dL}$ ). Dalam hal ini dapat dikatan bahwa pemberian pakan aterogenik beras jagung yang 
ditambahkan dengan lemak kambing dan kuning telur dapat meningkatkan kadar kolesterol total dalam darah tikus. Meningkatnya kadar kolesterol total dalam penelitian ini disebabkan meningkatnya jumlah konsumsi asam lemak jenuh dan adanya radikal bebas akibat dari proses hidrolisis dan oksidasi saat pemanasan lemak. Peningkatan kadar kolesterol total ini disebabkan meningkatnya jumlah konsumsi lemak, diet asam lemak jenuh dapat meningkatkan konsentrasi kolesterol darah 15-25\% (Guyton and Hall, 1996). Dalam Grafik diatas terlihat bahwa pada pengujian ke 3 , K- $(172,33)$ yang mengkonsumsi pakan aterogenik kadar kolesterolnya menurun, hal ini disebabkan karena pakan tinggi kolesterol belum terserap dengan baik oleh tubuh sehingga menyebabkan penurunan yang tidak stabil. Pada pengujian ke 4 dan 5 kadar kolesterol pada P1 dan P2 mengalami penurunan lebih rendah dibandingkan pengujian sebelum-sebelumnya, hal ini disebabkan adanya tambahan waktu pakan tinggi kolesterol disertai dengan penginduksian ekstrak daun gedi merah pada tikus yang diserap baik oleh tubuh sehingga menurunkan kadar kolesterol darah tikus. Pemberian ekstrak daun gedi merah yang ditambahkan selama dua minggu pada kelompok perlakuan P1 dan P2 mampu memberikan pengaruh yang bermakna.

Tabel 3 - Penurunan kadar kolesterol total (mg/dL)

\begin{tabular}{|c|c|c|c|c|c|}
\hline \multirow{2}{*}{$\begin{array}{c}\text { Kelompok } \\
\text { Perlakuan }\end{array}$} & \multicolumn{4}{|c|}{ Kadar Kolesterol (mg/dL) } & \multirow{2}{*}{$\begin{array}{c}\text { Rata-rata Penurunan Kadar Kolesterol } \\
(\mathrm{mg} / \mathrm{dL})\end{array}$} \\
\cline { 2 - 5 } & 1 & 2 & 3 & 4 & 17,0 \\
\hline K & 13,60 & 4,20 & 37,40 & 12,80 & $-17,6$ \\
\hline K- & $-13,34$ & 31,84 & $-77,67$ & $-11,33$ & 2,4 \\
\hline P1 & $-47,16$ & $-34,67$ & 74,17 & 1,83 & $-12,8$ \\
\hline P2 & $-82,70$ & 34,50 & 94,25 & 5,00 & 2 \\
\hline
\end{tabular}

Keterangan: K: Kelompok Perlakuan Kontrol diberi beras jagung $\mathrm{P}_{1}$ : Kelompok Perlakuan Ekstrak Etanol Daun Gedi Merah 20 mg/kgBB, P2: Kelompok Perlakuan Ekstrak Heksana Daun Gedi Merah 20 mg/kgBB.

Tabel 4 - Presentase penururunan kadar kolesterol total (mg/dL) terhadap kelompok K-

\begin{tabular}{ll}
\hline Kelompok Perlakuan & Penurunan Kadar Kolesterol Total (\%) \\
\hline K & $96 \%$ \\
P1 & $14 \%$ \\
P2 & $72 \%$ \\
\hline
\end{tabular}

Pada penelitian digunakan dosis $20 \mathrm{mg} / \mathrm{kgBB}$, dosis ini sudah dapat menurunkan kadar kolesterol total yang cukup signifikan dibandingkan dengan kelompok perlakuan K-. Pada kelompok perlakuan P1 yang diinduksikan ekstrak etanol daun gedi merah, penurunan rata-rata kadar kolesterol total mencapai $14 \%$ atau sekitar $2,4 \mathrm{mg} / \mathrm{dL}$ dan P2 yang diinduksikan ekstrak heksana daun gedi merah penurunan rata-rata kadar kolesterol total mencapai $72 \%$ atau sekitar $12,8 \mathrm{mg} / \mathrm{dL}$. Penurunan tersebut dapat mempertahankan nilai rata-rata kadar kolesterol pada kondisi normal. Dalam hal ini, ekstrak heksana daun gedi merah mempunyai aktivitas antikolesterol serta dengan adanya perbedaan yang signifikan dengan kontrol negatif yang hanya diberikan pakan aterogenik. Sedangkan kelompok perlakuan kontrol mencapai 96\% atau sekitar 17,0 $\mathrm{mg} / \mathrm{dL}$. Aktivitas antikolesterol dalam ekstrak daun gedi merah disebabkan adanya kandungan penting dalam daun gedi merah antara lain flavonoid, tanin dan fenolik. Flavonoid yang berfungsi sebagai antioksidan, mempunyai efek terhadap perbaikan lipid serum, modifikasi LDL teroksidasi, dan kecepatan metabolisme. Daun gedi merah juga mengandung tanin yang berfungsi sebagai antioksidan, astringent dan hiperkolesterolemia. Tanin bekerja dengan cara bereaksi dengan protein mukosa dan sel epitel usus sehinggga menghambat penyerapan lemak. Kandungan serat dalam daun gedi merah bermanfaat untuk menghambat absorbsi kolesterol di usus sehingga berpotensi menurunkan kadar kolesterol.

\section{Kesimpulan}

Berdasarkan penelitian yang telah dilakukan, dapat disimpulkan bahwa penginduksian ekstrak heksana daun gedi merah dan ekstrak etanol daun gedi merah dengan dosis $20 \mathrm{mg} / \mathrm{kgBB}$ dapat menurunkan kadar kolesterol total pada tikus dan yang paling banyak menurunkan kadar kolesterol total pada tikus adalah pemberian dengan ekstrak heksana daun gedi merah sebesar $72 \%$ atau sekitar $12,8 \mathrm{mg} / \mathrm{dL}$, dibandingkan dengan ekstrak etanol 
daun gedi merah yang hanya menurunkan kadar kolesterol sebesar $14 \%$ atau sekitar $2,4 \mathrm{mg} / \mathrm{dL}$.

\section{Daftar Pustaka}

Assagaf, F., A. Wullur, dan A. Yudistira. 2013. Uji Aktivitas Ekstrak Etanol Daun GediMerah (Abelmoschus manihot L.) Terhadap Tikus Putih Jantan Galur Wistar (RattusnorvegicusL.) Jurnal IImiah Farmasi. 2: 2327.

Budiyono, W., dan Candra, A. 2013. Perbedaan Kadar Kolesterol Total dan Trigliserida Sebelum dan Setelah Pemberian Sari Daun Cincau Hijau (Premna oblongifolia Merr) pada Tikus islipidemia. Journal of Nutrition College. 2: 118 - 125.

Gani, N., L.I, Momuat, dan M.M, Pitoi. 2013. Profil Lipida Serum Tikus Wistar yang Hiperkolesterolemia pada Pemberian Gedi Merah Abelmoschus manihot L. J. MIPA UNSRAT Online. 2: 44-49.

Guyton and Hall. 1996. Buku Ajar Fisiologi kedokteran. Edisi 9. EGC, Jakarta.
Mamahit, L., dan N.H. Soekamto. 2010. Satu Senyawa Asam Organik Yang Diisolasi dari Daun Gedi (Abelmoschus Manihot L. Medik) Asal Sulawesi Utara. Chem. Prog. 3: 42-45.

Tiwari, P., B. Kumar., M. Kaur., G. Kaur, dan H. Kaur. 2011. Phytochemical Screening and Extraction: A Review. Journal International Pharmaceutical Sciencia. 1: 98-106

Novriani. 2009. Perbandingan Aktivitas Antioksidan Dari daun Gedi hujau dan merah [Skripsi]. UKIT, Tomohon.

Sirait, C.H. 1986. Telur dan Pengolahannya. Pusat Penelitian Pengembangan Peternakan, Bogor.

Masrufi, M. M. 2009. Pemeriksaan HDL dan LDL Kolesterol sebagai Parameter Penaksiran Resiko Penyakit Jantung Koroner. Fakultas Kedokteran. Universitas Airlangga, Surabaya.

Murray, R.K., D.K. Granner, P.A. Mayes, and V.W. Rodwell. 2003. Biokimia Harper. Edisi ke24. Terjemahan Hartono, A. EGC, Jakarta 